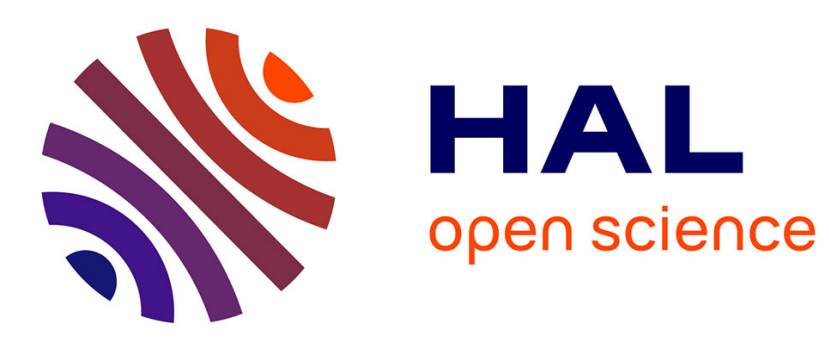

\title{
What Is the Meaning of the Extreme Variability of Ancient Ironworking in West Africa?
}

\author{
Caroline Robion-Brunner
}

\section{To cite this version:}

Caroline Robion-Brunner. What Is the Meaning of the Extreme Variability of Ancient Ironworking in West Africa?. Mobile Technologies in the Ancient Sahara and Beyond, 1, Cambridge University Press, pp.290-314, 2020, 10.1017/9781108908047.010 . hal-03001518

\section{HAL Id: hal-03001518 https://hal.science/hal-03001518}

Submitted on 5 Nov 2021

HAL is a multi-disciplinary open access archive for the deposit and dissemination of scientific research documents, whether they are published or not. The documents may come from teaching and research institutions in France or abroad, or from public or private research centers.
L'archive ouverte pluridisciplinaire HAL, est destinée au dépôt et à la diffusion de documents scientifiques de niveau recherche, publiés ou non, émanant des établissements d'enseignement et de recherche français ou étrangers, des laboratoires publics ou privés. 
What is the meaning of the extreme variability of ancient ironworking in West Africa? A comparison between four case studies (Bassar region/Togo, Dogon Country/Mali, Korsimoro/Burkina Faso, Dendi/Benin)

\section{Caroline Robion-Brunner}

CNRS-TRACES, University of Toulouse, France

Iron production has played a part in the history of Africa for more than 2,500 years. The study of this specific human activity has demonstrated its exceptional significance, its historical continuity and an astonishing variability of practice. In sub-Saharan Africa, metallurgists developed different ways to produce the same material: iron. They multiplied the technical choices to a degree unequalled on other continents. But what is the significance of such extreme diversity?

In this paper, we will detail four case studies representing different situations: in the Dendi country/Benin, where the question of the nature of the raw materials is considered; in the Dogon country/Mali, seven contemporaneous smelting traditions in a limited geographical area; at the Korsimoro site/Burkina Faso, five successive smelting traditions in the same place; and in the Bassar region/Togo, the impact of ancient and intensive iron production on the environment and on the technology. Based on these examples we discuss the interpretation of diversity in terms of the history of technology and population dynamics

Keywords: Variability, Iron, Metallurgy, West Africa 


\section{Introduction}

One of the original features of African ironworking is its extreme variability. African metallurgists developed different ways to produce the same material: Iron. Compared to the Europeans, ${ }^{1}$ they multiplied the technical and cultural choices to a degree unequalled. In Africa, only the bloomery process has been used, but dozens of variants of this process have been developed.

This diversity has long enabled research to compare the techniques used, ${ }^{2}$ reconstruct changes in techniques over time, ${ }^{3}$ and examine population settlement patterns. ${ }^{4}$ Several analytic systems have tried to characterize the variants and to understand their presence: Why in Africa are there so many methods to make iron?

\section{$<<$ Figure 1>>}

At present, four recent research projects offer the possibility of re-examining the diversity of iron smelting, not on a continental but regional scale (Figure 1). For my PhD (10 field seasons between 2002 and 2010), ${ }^{5}$ more than a hundred bloomery and mining sites were inventoried, mapped and studied for the first time in the Dogon country, Mali. ${ }^{6}$ This study highlights an outstanding archaeological heritage of iron metallurgy and the selection of revelant criteria to differentiate seven iron traditions. This analytic method was then tested in 2013 and 2014 ${ }^{7}$ in Dendi country (Benin) to understand the development and importance of iron production. ${ }^{8}$ Here again, there are several different iron traditions in a specific area. Known as one of the most important African ironworking centres, ${ }^{9}$ it is clear why de Barros suggested the Bassar region (Togo) to me to address the issues of societal and environmental impact of ancient iron production. ${ }^{10}$ In 2013, the "SIDERENT" project was selected for support by the French research agency (ANR). The innovative character of this project consists in mobilizing researchers from five different disciplines (ethnology, archaeology, archaeometry, metallography and environmental sciences) and in addressing the social, ritual and symbolic dimensions, the nature of the exploited resources and the technologies utilized, as well as the economic and political contexts within which iron production developed. Since 2011, Serneels has led research in Burkina Faso and Côte $d^{\prime}$ Ivoire. ${ }^{11}$ In Burkina Faso, he found an immense iron production site, Korsimoro, where five chronologically consecutive technical traditions were identified. Our use of the same methodological approach allows us to compare our data.

\footnotetext{
${ }^{1}$ Pleiner 2000.

${ }^{2}$ Cline 1937.

${ }^{3}$ Killick 1991; 2015.

${ }^{4}$ David and Robertson 1996.

${ }^{5}$ This PhD was realized in the framework of the project entitled "Human populations and paleoclimatic evolution in West Africa", directed by Eric Huysecom (Huysecom 2002).

${ }^{6}$ Robion-Brunner 2010; Robion-Brunner et al. 2013.

7 These two missions were carried out in the framework of the "Crossroads of Empires" project led by Anne Haour (Haour et al. 2011).

${ }^{8}$ Robion-Brunner in prep; Robion-Brunner et al. 2015.

${ }^{9}$ de Barros 1985; 1986; 1988.

${ }^{10}$ Since 2014, the team of the "SIDERENT, Iron smelting and environment in Togo" project led by Caroline Robion-Brunner has conducted three field seasons (Robion-Brunner et al. 2014).

${ }^{11}$ These researches have been the subject of the project entitled the "Origine et développement de la métallurgie du fer au Burkina Faso et en Côte d'lvoire" led by Vincent Serneels (Serneels et al. 2012; $2013 ; 2014 ; 2015)$.
} 
In this contribution, we see via the case studies each of the factors that caused diversity in African iron smelting. First of all, we begin with the material constraints and the adaptations of the metallurgists. Next, we examine the link between the diversity of iron traditions and the identity of metallurgists. Certain similarity between traditions perhaps reflects the transmission of knowledge and mechanisms by which technologies are learnt. The scale of production also has an impact on the bloomery process. We will see that certain iron traditions may support intensive production. We conclude with thoughts on possible distinctions between culture, economic context and population dynamics to explain the extreme variability in African ironworking and on possible future researches to better understand this question.

\section{Diversity in African iron smelting: a phenomenon still under debate}

Since the pioneering work of $\mathrm{W}$. Cline, ${ }^{12}$ many researchers have attempted to explain this considerable diversity. To this end, different typological systems have been developed. The first is based on furnace morphology ${ }^{13}$ and considers the shapes and sizes of the superstructure, number of openings, construction materials, etc. The second is based on technological criteria in order to identify iron-smelting practices: presence or absence of a superstructure, natural or forced draught, tapped slag or slag pit furnace. ${ }^{14}$ The third classifies metallurgical workshops based on social, political and economic organization, ${ }^{15}$ taking into consideration the social identity of the metallurgists. These typological systems have showed the diversity of technological, cultural and economical choices but do not explain why or clarify the underlying meaning of this phenomenon.

In 1991, Childs asks the question of 'why a great diversity of iron smelting furnaces exists in sub-Saharan Africa'. ${ }^{16}$ She discusses the factors involved in stylistic variation and concludes: 'the great diversity of iron smelting furnaces in Bantu-speaking Africa is related to the many localized, cultural influences on the smelting process'. ${ }^{17}$ Through this technological activity, African societies 'express their views of the structure of nature and society'. ${ }^{18}$ Beyond the material requirements, ironworking is also charged with meaning. The bloomery process is a difficult process to execute because specific chemical and physical conditions must be met if metallic iron is to be made. It is no little matter for humans to have the skills to change ore in metal, to modify the properties of a natural resource to a useful material, to reduce iron oxide to metallic iron. Study of the methods of iron smelting can reveal belief systems, rituals which mark the technical acts, technical alternatives, and cultural preferences developed by the metallurgists. ${ }^{19}$

These questions on technological choices are often masked by the debate on the origins of ironworking in Africa. For over 60 years, it is still relevant and finds a

\footnotetext{
${ }^{12}$ Cline 1937.

${ }^{13}$ Celis 1991; Martinelli 1993; McNaughton 1993; Sutton 1985.

${ }^{14}$ Chirikure et al. 2009; Kense 1985; Killick 1991; Miller and Van der Merwe 1994; Pole 1985; Tylecote 1987.

${ }^{15}$ Childs and Killick 1993; Langlois 2005-06; de Maret 1980; 1985; Martinelli 2004.

${ }^{16}$ Childs 1991, 332.

${ }^{17}$ Childs 1991, 353.

${ }^{18}$ Childs and Killick 1993, 333.

${ }^{19}$ Childs 1991; Gordon and Killick 1993; Herbert 1993; Schimdt 1996.
} 
prominent place in the Africanist archaeologist community. ${ }^{20}$ Even if the majority of scientists agree upon the independence of the invention of African iron metallurgy, they continue to debate the early dates. Behind these discussions, we have the political history of the relationship between Europe and Africa, and the difficulty in simply examining the raw data. With this debate on the oldest dates, we lose sight of the technical aspects of the first smelting processes put in place and the evidence of their spread across Africa. Like Gallay, ${ }^{21}$ Killick encourages Africanist archaeologists to move beyond the issue of "diffusion or invention". 22 For him, the confusion between invention and innovation leads to an erroneous idea of the historical evolution of African ironworking and crystallises the debate on the capacity or not of Africans for technological invention. The huge variation in African iron smelting practices is not called into question: 'African ironworkers invented many novel iron-smelting processes. Some of these have not yet been noted anywhere else in the world' ${ }^{23}$ But for inventions to become innovations, several conditions should be present: dense populations, large towns and cities, and literacy. Both historical and archaeological researches show a low population density in sub-Saharan Africa before the 17th century and a pattern of settlements with large empty spaces between them. These factors seem to have favoured not the development of innovations, but rather the presence of many variants of the bloomery process in Africa.

It is not new to connect technical and social phenomena. The study of technological systems is as much the affair of the archaeologist as the ethnologist. ${ }^{24}$ Given the fact there are different ways to smelt iron ore, trying to explain these variants is to explore not only their material but also socio-cultural context. This highlights generally relevant links between a technical phenomenon and a social reality. By contrast with studies that take into account the distribution of technical parameters on the scale of the African continent, ${ }^{25}$ new systematic regional surveys made of West African iron districts allow us to revise our thinking. ${ }^{26}$ These surveys contribute to seeing diversity in a single area, change or continuity over time and the causes of duration over time or change in a technical iron tradition.

\section{Adaptation to local conditions: which raw material for smelting?}

Africa is a vast continent with variable local conditions. The diversity of raw material leads to some adaptations of the bloomery process. This enterprise, the smelting of ore to metal, demands specialised skills in maintaining a balance between the different variables for it to be successful. In nature, iron may be found in five different compositions: oxide, hydroxide, carbon, sulphide and silicate. Even if the oxides (hematite and goethite) present in the lateritic formations are the most common ore in Africa, they are many different types of iron ore. Such variability could influence the technology used to smelt them and thus the diversity seen in the slag produced. For

\footnotetext{
${ }^{20}$ See notably the volume 8 (1) 2010 of Journal of African Archaeology; Alpern 2005; Bocoum 2004; Clist 2012; Holl 2009; Killick 2004; Mauny 1952; Trigger 1969.

${ }^{21}$ Gallay 2001.

22 Killick 2015.

23 Killick 2015, 314.

24 Balfet 1975; Chamoux 1978; Lemonnier 2010; Leroi-Gourhan 1971; Mauss 1947.

${ }^{25}$ Chirikure et al. 2009; Kense 1985; Killick 1991.

${ }^{26}$ Fabre 2009; Guillon 2013; Robion-Brunner 2010; Robion-Brunner in prep; Robion-Brunner et al. 2015; Serneels et al. 2012; 2013; 2014; 2015.
} 
example, the melting point depends on the nature of the ore. Killick, in his paper on 'Invention and Innovation in African Iron-smelting Technologies' argues that 'African ironworkers adapted bloomery furnaces to an extraordinary range of iron ores, some of which be cannot be used by modern blast furnaces' ${ }^{27}$ He took the example of magnetite-ilmenite ores used both in northern South Africa ${ }^{28}$ and in the Pare mountains of northern Tanzania ${ }^{29}$ : 'High-titanium iron ores can be smelted in bloomery furnaces because these operate at lower temperatures and have lessreducing furnace atmospheres than blast furnaces'.$^{30}$

$<<$ Figure 2>>

$<<$ Table 1 $>>$

Some areas contain several different iron ores and archaeometric analyses show that metallurgists made conscious or unconscious choices amongst these to produce their iron. In the southern and northern Republic of Benin, slag and ore were collected from six archaeological contexts (Figure 2). ${ }^{31}$ Our first analysis of the global chemical compositions of the slag sampled reflects differences in the choice of raw materials from place to place (Table 1). ${ }^{32}$ Indeed, at Kompa Moussekoubou and Gorouberi a lateritic ore was employed whereas at Tin Tin Kanza, Mommassaga and Gbanago, an oolitic ore was used. Evidence for the mining of the oolitic ore exists, ${ }^{33}$ notably at Pekinga, but the mining of a lateritic ore still remains to be proved. The geological map shows the presence of soils that could contain some nodules of iron and manganese oxides or of a lateritic crust (from yellow to brown on the map, Figure 3 ) that could have been exploited and that could explain the specific compositions measured in the slag of Kompa and Gorouberi. The oolitic ore is well known to be present in the layer of the terminal Continental in Dendi country (purple on the map, Figure 3). ${ }^{34}$

$<<$ Figure $3>>$

On the basis of the geological data, some preliminary hypotheses concerning the ore can be proposed but will need to be supported by collecting and analysing more samples both in the mining areas and at the smelting sites. Further archaeological investigations and archaeometric analyses are necessary to understand how culture, economics, and technical pressure play a part in choosing the raw materials, in the smelting process and in the treatment of the metal produced in Dendi country. It is interesting to see that the ironworkers of Kompa Moussekoubou did not choose the nearest iron ore. Behind the constraint of raw materials, there can also be the issue of political control over resources. The landholder could force metallurgists to use their ore or to obtain it elsewhere, perhaps of a lesser quality. It is important to take into

${ }^{27}$ Killick 2015, 314.

${ }^{28}$ Killick and Miller 2014.

${ }^{29}$ Louise lles pers. comm., 2013.

${ }^{30}$ Killick 2015, 314.

${ }^{31}$ Robion-Brunner et. al 2015.

32 Marie-Pierre Coustures (Toulouse University) was responsible for archaeometric analyses on the metallurgical samples. Chemical compositions of the minerals were determined by electron microprobe analysis and global compositions measured by ICP-AES (Induced Coupled Plasma Atomic Emission Spectrometry) and ICP-MS (Induced Coupled Plasma Mass Dispersive Spectrometry).

${ }^{33}$ The oolitic ore present in the north of Dendi country was sampled at Pekinga (Figure 1) and analysed. The thin section analysis shows it is mainly composed of goethite ( $2 \%$ of $\mathrm{P}_{2} \mathrm{O}_{5}$ in the ancient oolites) with interstitial quartz, sillimanite and rutile cemented by goethite. The high $\mathrm{P}_{2} \mathrm{O}_{5}$ content appears too in the global composition (Table 1).

${ }^{34}$ Viennot 1978. 
account the relationship between the different actors involved in iron production. The identity of the metallurgists is plural: different statuses (landholders, possessors of magic and technological knowledge, labour force) operate at each of the principal stages of the bloomery process (extraction, smelting, smithing), and depend on the level of production. In the Dogon country, the available ethnological data yields valuable information concerning the situation in the later periods of traditional iron production (18th century to the beginning of the 20th century $A D$ ) and allow determining the identity of ironworkers. In this area, 'the holder of the land from which the iron ore was extracted belongs to the social category of the cultivators. Indeed, the mines are always situated within the respective village's territories, which are under the responsibility of the land masters (descendants of the village founders). The technically more complex blacksmithing activities are a domain exclusively executed and controlled by the blacksmiths, and gives them their status of endogamous craftspersons separate from the cultivators' ${ }^{35}$ The local heterogeneity in technological practice and the archaeological evidence could be the result of the control of resources.

Wood, or wood transformed into charcoal, was the most important fuel for African iron smelting. The wood species which can be used are numerous, although naturally the metallurgists prefer those with a high burning value. In Africa, the vegetation is quite variable and affected by climate and different human impacts. So, we can observe different choices in fuel use reflecting local conditions. For example, in the Dogon country, ironworkers used several wood species to smelt iron. 'This corresponds well with Kiethega $(2009,249 \mathrm{ff}$.) who similarly lists a large number of species traditionally used for iron production in Burkina Faso. [...] The spectra are nevertheless dominated in number by some taxa, namely Prosopis Africana and Terminalia species, Vittellaria paradoxa and Pterocarpus lucens followed by members of the Combretaceae family'. ${ }^{36}$ This non-selectivity of wood species contrasts with the situation observed on the Meroe sites, in Sudan. The charcoal analysis results show a high selectivity in fuel use because only one species was exploited, the Acacia nilotica. This is not the only taxon in the area; the composition of the anthracological samples is completely different in the domestic sites and more diversified. ${ }^{37}$ These choices linking both strategies of exploitation and adaptation to the local conditions may also be reflected in the bloomery process. The natural-draft furnaces require a lot of fuel; their geographical distribution 'corresponds exactly to the areas of infertile, dry, deciduous savanna woodlands in Africa, in which trees were plentiful'. ${ }^{38}$ Therefore, it makes sense that Dogon ironworkers used a varied spectrum of wood to produce their iron. They needed a huge quantity of charcoal to operate their natural-draft furnaces and could not be too selective if they did not want to damage the environment. For the Meroe sites, excavations have yielded six pots that had been used as bowls for bellows surrounding the furnace dated to around AD 200. ${ }^{39}$ This is the earliest and best-known archaeological bellows from Africa. The forced draught needs less charcoal than the

\footnotetext{
${ }^{35}$ Robion-Brunner et al. 2013, 263.

${ }^{36}$ Eichhorn 2012, 144-145.

${ }^{37}$ Barbara Eichhorn pers. comm., 2014.

38 Killick 2015, 313-314.

${ }^{39}$ Shinnie 1985.
} 
natural-draft process. The Meroe ironworkers may have had a selective strategy for a long time.

\section{Show me your slag, l'll tell you who you are!}

Similar to many stylistic analyses of ceramics, differences in iron technologies reflect social identity. ${ }^{40}$ The style or the way something is done is generally conceived as the assertion of an identity. It cannot be conceived without opposition and a sense of otherness. ${ }^{41}$ It signals the customs of a specific group of people. Moreover, craftsmen recognise themselves by the way in which they make things. Analyses of the material data distinguish between the different traditions, the identity of the metallurgists and conclude with the proposal of scenarios to help explain settlement history.

The diversity of African ironworking is of much interest to specialists of techniques in terms of ways of "making" and "thinking" about the actions applied to the material. In addition to ways of "thinking", there are also technical, social and cultural factors. It is thus logical to consider which driving forces crosscut this variability. For Childs, "iron smelting furnaces exhibit style. [...] I define technological style as the formal integration of the behaviours performed during the manufacture and use of material culture which, in its entirely, expresses social information". ${ }^{42}$ The term "style" allows inclusion of all the factors involved in the observed diversity and contributes to a better understanding of it. Furnaces, slag and the spatial organisation of iron workshops materialize the beliefs, skills, economic context, identity and history of the metallurgists. It should be noted that ironworkers are aware that there are many different techniques to produce iron, and that it is possible to distinguish them. Like potters and pots, ironworkers recognize their slag.

\section{$<<$ Figure 4>>}

In the Dogon Country (Mali), seven smelting traditions have been identified (Figures 1 and 4). ${ }^{43} \mathrm{~A}$ series of fourteen AMS dates and oral traditions show that this activity started at least in the beginning of the second millennium $A D$ and gradually ceased in the early 20th century, taken over by imported European iron. Six of the seven traditions produced iron at the same time between the $16^{\text {th }}$ and the $18^{\text {th }}$ centuries. While all metallurgical traditions of this region use a low-temperature, natural draft bloomery iron smelting process, the individual technologies show more or less substantial differences in furnace morphologies, the slag separation process, and the type and nature of the waste products. A slag-tapping process characterizes the Fiko, Ouin, Ama, Wol and Tinntam traditions; a substantial part of the slag from these sites was tapped and shows more or less specific morphologies. The Aridinyi smelters used slag-pit furnaces, and the slag formed large furnace slag blocks in the pit. The Ennde furnaces did not have tap holes, and the slag flowed into the lower part of the furnace, where it cooled down with characteristic, intricate vertical flow structures. From a morphological point of view, the furnaces of the different traditions demonstrate a high degree of architectural diversity. In a geographically limited area, the Dogon metallurgists showed creativity in the construction of bloomery structures. All of the bloomery furnaces have a pit, mostly of circular section, and a door to remove slag and

\footnotetext{
${ }^{40}$ Celis 1991; Sutton 1985.

${ }^{41}$ Gallay 2000.

${ }^{42}$ Childs 1991, 332.

${ }^{43}$ Robion-Brunner 2010; Robion-Brunner et al. 2013.
} 
raw iron. However, the number of openings, the presence or absence of stairs or peephole, and the nature of the construction materials differ. In the end, each tradition has its own characteristic bloomery structures; of course, this does not exclude a degree of variability within a single tradition, in particular for those that persisted over long periods. From an economic point of view, the spatial organization and volume of slag heaps indicate high diversity in the intensity and level of production. Enormous craters of waste, with fifteen sites each, distinguish the Fiko tradition containing a slag volume of more than $10,000 \mathrm{~m}^{3}$. Sites in the Tinntam and Aridinyi traditions generally have volumes between 1,000 and $10,000 \mathrm{~m}^{3}$. The spatial organization and waste volume for the Ouin, Ama, Wol and Ennde traditions reflect smaller scale metallurgies, with slag volumes on the order of 10 to $1,000 \mathrm{~m}^{3}$. A global estimate of the tonnage of slag is in the region of 400,000 tonnes - or 40,000 tonnes of iron objects over 1400 years,$-{ }^{44}$ of which more than $75 \%$ belong to the Fiko traditions. The radiocarbon dates at Fiko show an intensification of production between AD 1000 and 1600 destined for a vast external market.

This diversity of primary iron production in a geographically limited area, and extending over several centuries, is surprising. It suggests that technological differentiation should not be considered from a purely functional perspective because functional factors do not satisfactorily explain the causes underlying the observed variability. Cultural and economic factors are essential if we want to study and understand metallurgical production as a whole. The diversity of the metallurgical remains is certainly also related to the complex historical context of this region, where the identity of the metallurgists is expressed through material culture. Ethnohistorical data reveal that the smith caste on the Bandiagara Plateau developed out of the local population substrate, but also shows that other persons were incorporated into this caste from other populations, which later arrived in this area, mostly from the Inland Niger Delta, but also from the northwest and north-east of the Gondo Plain. These individuals did not originally all belong to the social category of smiths. Following a voluntary or restrained social transformation, local cultivators, of Dogon or external origin, and slaves became iron specialists to meet economic needs. The information collected shows a level of production that goes well beyond local needs, or even those of the entire Dogon Country. Increasing external demand, which could tentatively be related to the emergence of the West African Empires, may have driven the intensification of production. This economic and historical context allows the encounter between diverse populations with different metallurgical traditions. These populations shared a territory and had to maintain their methods of producing iron as a cultural signature. However, the presence of a certain similarity between the metallurgical traditions perhaps shows the existence of technological transmission. In the Dogon country, there was no population replacement but rather cohabitation in the same space of several human groups of different geographic and social origins. ${ }^{45}$

\footnotetext{
44 Through the quantification of slag (Robion-Brunner 2010) and the material mass balance established at the Fiko site (Perret and Serneels 2006), we can propose an estimation of iron production: each tonne of slag corresponds to a iron production of between 300 and $600 \mathrm{~kg}$, so 400,000 tonnes of slag = 120,000 tonnes of bloom; after refining of the bloom and the smithing of iron objects, 100 to $200 \mathrm{~kg}$ of iron objects can be expected to have been produced, so 120,000 tonnes of bloom $=40,000$ tonnes of iron objects. 40,000 tonnes of iron objects produced over 1400 years corresponds to 26 tonnes of iron objects by year (without taking account fluctuation in the production).

${ }^{45}$ Robion-Brunner 2012.
} 
The preservation of variants within the same region could reflect the mechanisms by which technologies are learnt. Depending to the technology (ironworking, ceramics, weaving, etc.), the mechanisms of apprenticeship would facilitate or not the conditions of adoption of exogenous technical skills and the agency to adapt techniques and technological approaches. The forces of the beliefs underlying the techniques may restrain and model each step of the chaîne opératoire. In contrast to ceramics ${ }^{46}$ and forging, ${ }^{47}$ the apprenticeship of iron smelting has not been the focus of ethnological studies. Researchers have, however, described "real" or re-enacted smelting sessions that they attended. They discuss technical and quantified details, beliefs and rituals claimed for the success of the operations, and finally social and economic context. ${ }^{48}$ The status of the participants is given. There is one head smelter or an elder's council, and young people or apprentices. These ethnographic descriptions show the major importance of rituals. They mark each step and allow them to be remembered. Under the leadership of a master, the metallurgists seem to take part collectively in the smelting. Even if the learning can be individual, ${ }^{49}$ smelting is really collective; it is impossible to smelt alone. The apprentices need to follow and remember the rituals, but they do not seem to learn technical knowledge. Each member of a smelting session detects physical and chemical changes of the material being processed inside the furnace through different senses: sight, hearing, smell and touch. ${ }^{50}$ If the smelting does not work, the behaviours of the master and the group are not called into question. Instead, a taboo has been transgressed. The success of a smelt is guaranteed by the respect of taboos, ancestors, traditions, geniuses, etc. 'dans le domaine de la métallurgie traditionnelle du fer en Afrique, les croyances sont indissociables des techniques et forment ensemble une pratique complexe dont le résultat immédiat est la production de richesse sociale au service de la collectivité' ${ }^{51}$ It is therefore difficult to innovate in a technical activity with a deep-seated symbolic system. Beyond expertise, the head smelter transmits a way of viewing the world and the kills to modify it. These skills are both technological and magical in scope.

\section{Big or small, it is not the same!}

The quantity, large-scale or small-scale, makes a difference. The metallurgists do not manage their space and their production in terms of quantity and quality in the same way. The artefacts cannot be the same in the different levels of production. Varying production output modifies the raw material supply networks, the organization of the site and the structure of production. 'Furnace size was also influenced by local economic and social phenomenon, such as market demands, long distance trade networks, the use of bride price, and the available labor pool. These were usually unconscious relationship set in tradition within a wide cultural context'.$^{52}$

$<<$ Figure 5>>

\footnotetext{
${ }^{46}$ Bril and Roux 2002; Gallay 2010; Gosselain 1995.

${ }^{47}$ Kante 1993; Martinelli 1996.

48 Bellamy 1904; Echard 1986; Huysecom and Agustoni 1997; Van der Merwe and Avery 1987.

49 Jane Humphris pers. comm., 2015.

${ }^{50}$ Andrieux 2012.

${ }^{51}$ Huysecom 2001, 82.

52 Childs 1991, 345.
} 
At Korsimoro (Burkina Faso), five smelting traditions have been identified in the same place $^{53}$ and the 18 radiocarbon dates obtained show that these traditions follow one another in time and each correspond to a different period of production (Figure 5). ${ }^{54}$ The KRS 1 tradition (7th to 10th century AD) is characterized by average-sized furnaces (diameters of $0.8 \mathrm{~m}$ ) with natural draught and single utilization. The furnaces are grouped in lines of 5 to 12 units. In the KRS 2 tradition (11th to 13th century AD), the furnaces are larger (diameters of $1 \mathrm{~m}$ ), with natural draught and multiple utilizations. The slag is caught at the back of the furnace in which used tuyeres have been placed. Scraps form a large but not very thick spread. The KRS 3 tradition (14th to 16th century $A D$ ) sees the appearance of furnaces with slag spilling outside (natural draught/multiple utilization/reconstruction in the same place). Each furnace is surrounded by a circular accumulation of slag. The furnaces of the KRS 4 tradition (17th century $A D$ ) are very small (diameters of $0.2 \mathrm{~m}$ ), with a single utilization and forced draught. They are placed in lines or in groups. The KRS 5 tradition (18th/19th century $A D$ ?) seems to belong to the last period of production. The slag heaps are small ( 0.1 to $1 \mathrm{~m}$ high) with large furnaces (diameters of $1.5 \mathrm{~m}$ ) installed among them, without particular organization. No opening in furnaces has been seen, but the local informants mention the simultaneous use of four bellows. A global estimate of the tonnage of slag is in the region of 200,000 tonnes, of which more than $80 \%$ belong to the second and third traditions. These volumes testify to intensive production between $A D 1000$ and 1500, destined for a vast external market. ${ }^{55}$ In the current state of knowledge, there are no arguments to explain these technical changes. They seem rather radical because Serneels does not detect gradual evolution from one technique to another. It has been argued that these technical changes can be viewed as significant changes in settlement history. It is very difficult to discuss continuity or discontinuity in iron production. If the technical changes correspond to movements of population, we could envisage periods of abandonment between two phases of activity. Only the iron workshops of KRS 2 were re-occupied by those of KRS 3 during the next period which could support continuity of activity. The transitions between KRS $1 /$ KRS 2, KRS 3/KRS 4, and KRS 4/KRS 5 are also unclear. The available radiocarbon dates are too few to discern the evolution of iron production at this site. To clarify such change, additional radiocarbon dates are needed as well as work on other types of sites and artefacts (settlements, burial sites, ceramics, etc.).

When discussing continuity between two traditions, development and innovation can play a significant role. Certain techniques may support modifications, improvements, and adaptations in response to economic and social contexts. It is true that 'large-scale production was accomplished in furnaces of all sizes, however. The Njanja group of the MaShona, for example, mobilized a large labor force to operate many small furnaces simultaneously (Mackenzie 1975). Other groups used fewer, but larger furnaces with a slag outlet so that a bigger bloom could accumulate in the space left by the tapped slag (Tylecote 1962) ${ }^{\prime}{ }^{56}$ But certain technical systems are more effective for large-scale

\footnotetext{
53 The site extends almost continuously over $10 \mathrm{~km}$.

${ }^{54}$ Serneels et al. 2012; 2014.

55 Building on the calculation elaborated at the Fiko site (see footnotes 44 and Perret and Serneels 2006): 200,000 tonnes of slag $=60,000$ tonnes of bloom $=20,000$ tonnes of iron objects. $80 \%$ were produced between AD 1000 and 1500, for 16,000 tonnes of iron objects produced over 500 years, corresponding to 32 tonnes of iron objects per year.

${ }^{56}$ Childs 1991, 345.
} 
production. The possibility of re-using the same furnace several times limits the time needed for construction. This is related to the smelting process (slag runs into the bottom of the furnace or out of the furnace) and the capacity for cleaning the pit of the furnace for future use. We therefore suggest that multiple re-use of a furnace is an enabling factor for large-scale production.

Other technological elements could be influenced or encouraged by local economic needs. For example, the large natural draft iron-smelting furnace is considered by both Martinelli ${ }^{57}$ and Killick ${ }^{58}$ as a technological innovation. In choosing "natural draft", iron smelters opted for efficiency and labour saving, thereby using fewer workers than would have been necessary with mechanical blowers. For Martinelli, this choice is the result of social transformations and a reflection of the associated technological, cultural and political issues: 'The technical system of the Yatenga blacksmiths is characterised by the desire to produce surpluses for exportation to other areas in the Mossi (Moose) region and to neighbouring countries as far as the border with Ghana'. ${ }^{59}$ The choice of natural draft and the creation of a caste of blacksmiths frees up people to treat the raw iron, make iron objects and develop long-distance trade and exchanges. For Killick, the widespread use of this kind of furnace was favoured by local environmental conditions: 'These [large draft iron-smelting furnaces] were particularly common in the West African Sudanic woodland zone from Senegal to Nigeria and in the miombo woodlands of Tanzania, Zambia, Malawi and Mozambique (Cline 1937; Killick 1991). Both of these zones of savannah woodlands soils have very infertile soils, so swidden (slash-and-burn) agriculture was dominant. [...] I suggest that the labour requirements for swidden agriculture conflicted with those for iron smelting, and that this conflict favoured the spread of the natural draft furnace' ${ }^{60}$ Whether the result of economic or environmental pressure, several major West African centres of iron production (Dogon country/Mali, Bassar region/Togo and Korsimoro/Burkina Faso) used natural draft furnaces.

\section{Preliminary reflections on the meaning of the diversity}

African iron production is diverse and multiple. The data currently available to us comes from rover a century and a half of research. It is thus extremely difficult to determine the factors underlying the observed diversity, develop generalizations and propose explanations. Nevertheless, a number of recent research programs have contributed significantly to data renewal.

Africa has extremely diverse physical and environmental conditions. Metallurgists need to adapt their iron process to local resources, which play a significant role in the variability in iron waste and the processes used. To estimate their role, more analyses of global chemical compositions of the ore and the slag are needed as well as archaeobotanical investigations. In spite of these raw material constraints, metallurgists made a fundamental choice to exploit them. The issue of political control over resources could also be a factor in local heterogeneity in technological practices and the archaeological evidence. In the SIDERENT project then, we (archaeologists and archaeometrists) work with an ethnologist, Stephan Dugast, to understand the choices

\footnotetext{
${ }^{57}$ Martinelli 2004.

58 Killick 2015.

${ }^{59}$ Martinelli 2004, 187.

${ }^{60}$ Killick 2015, 316.
} 
and local perceptions of raw materials in the context of iron production and to identify the existence or not of natural resource management strategies to minimize the environmental impact in order to continue this activity.

Systematic regional studies show that iron smelting is an issue of style. Different ways to produce the same thing suggests the presence of populations of several cultures. Smelting techniques reflect social identity. But the presence of several smelting styles in a single area, such as Dogon country (Mali) and the Korsimoro site (Burkina Faso), can be proof of population movement, technical transmission or increased production. With archaeological artefacts alone, have we the elements to make differentiate between these hypotheses? With regional studies, we can acquire much information from different periods and examine whether metallurgical diversity is linked with one factor (raw material constraints, settlement history, technological transmission, technological evolution, economic level of production, etc.) or several. In the case of Dogon metallurgy, the presence of different traditions reflects the successive arrival of different population groups. Their long-term cohabitation reflects the desire or need for cultural differentiation, emphasised by methods of knowledge transmission. The forces of the beliefs underlying the techniques and their ability of maintaining the confidential character of this power - the power to change the nature of the material by secretes and fear is also a major component. At Korsimoro, all five metallurgical traditions belong to different periods. The presence in the last periods of two traditions producing a poor quality iron and in small quantity shows there is no linear evolution of technology. These technological changes were probably linked with significant changes in population settlement.

The final factor affecting technological diversity is the level of production. The same technological tradition is not used for both small and large-scale production. For smallscale production, a furnace, typically a slag-pit furnace; was generally used only a single time. For large-scale production, several elements are always present: multiple uses of a furnace, strategies to put out the slag during the smelt (tapping-slag) or after the smelt (used tuyeres or a block of clay placed in the furnace before the smelt), furnaces in battery system, organization of the waste, etc. In Dogon and Korsimoro iron production, we saw both the impact of population displacement and the impact of the economy. But, we do not as yet have material evidence that African iron smelters had adapted or changed their technique to intensive production, although it seems that certain techniques are more suitable for increased production. Further archaeological investigations and comparisons with European cases are necessary to better understand and validate this interpretation. To compare the African ironsmelting sites and African sites with European sites, we need to develop a common approach and improve the bridge between French and English terminology, particularly to describe the slag.

\section{Acknowledgements}

I am grateful to Aurélie Cuenod for inviting me to the Mobile Technologies conference and suggesting that $I$ present the results of my recent archaeological and ethnohistorical research on West African metallurgy, and to Marie-Pierre Coustures, Alain Gallay, Vincent Serneels, Pierre de Maret and David Killick for many discussions about diversity, techniques, African iron smelting, etc. I must also express my gratitude 
to François-Xavier Fauvelle for his valuable comments and Becky Miller for her helpful corrections of the English text.

\section{Captions for figures}

Figure 1. Map of West Africa, showing the case studies used in the text.

Figure 2. Map of Benin, showing the samples of ore and slag analysed in the laboratory (MPB = Pekinga; KMK = Kompa Moussekoubou; GOB = Gorouberi; MMS = Momassaga;

TTK = Tin Tin Kanza; GB1 = Gbanago).

Figure 3. The smelting sites of the Dendi country overlain on the soils map after Dubroeucq, Faure and Viennot, 1976 for the Kandi sheet and after Faure and Viennot, 1976 for the Karimama sheet. Potential oolitic ore deposits are shown in shades of purple and potential lateritic ore deposits in shades of ochre. The possible supply routes are represented by arrows.

Figure 4. Map of Dogon country, showing the extraction and bloomer sites, and the seven metallurgical traditions.

Figure 5. Synthesis of chronological data and stages of production at the Korsimoro site (after Serneels at al. 2014, fig. 49 p.102).

\section{Captions for Table}

Table 1. Global major element compositions of some ore and slag from the Dendi country measured by ICP-AES at ALS Minerals, Seville, Spain.

\section{Bibliography}

Alpern, S. B. 2005. Did they or didn't they invent it? Iron in sub-Saharan Africa. History in Africa 32: 41-94.

Andrieux, P. 2012. La réduction métallurgique: des sens aux savoirs transmis. In C. Robion-Brunner and B. Martinelli (eds), Métallurgie du fer et sociétés africaines : bilans et nouveaux paradigmes dans la recherche anthropologique et archéologique. Oxford: Bar International Series 2395, 227-243.

Balfet, H. 1975. Technologie. In R. Cresswell (ed.), Eléments d'ethnologie. 2, Six approaches. Paris: A. Colin, 44-79.

de Barros, P. 1985. The Bassar: large-scale iron producers of the West African savanna. Unpublished Ph.D. thesis, University of California, Los Angeles (USA).

de Barros, P. 1986. Bassar: A quantified, Chronologically, Controlled, Regional Approach to a Traditional Iron Production Centre in West Africa. Africa, Journal of the international African Institute 56.2: 148-174.

de Barros, P. 1988. Societal repercussions of the rise of large- scale traditional iron production: a West African example. The African Archaeological Review 6: 91-113.

Bellamy, C. V. 1904. A West African smelting house. Journal of the Iron and Steel Institute 66: 99-126. 
Bocoum, H. (ed.) 2004. The Origins of Iron Metallurgy in Africa. New Light on its Antiquity: West and Central Africa. Paris: UNESCO.

Bril, B. and Roux, V. (eds) 2002. Le geste technique. Réflexions méthodologiques et anthropologiques. Ramonville Saint-Agne: Editions Erès (Revue d'Anthropologie des connaissances, Technologies / Idéologies / Pratiques), vol. 14(2).

Celis, G. 1991. Les fonderies africaines du fer, un grand métier disparu. Francfort: Museum für Völkerkunde.

Chamoux, M.-N., 1978. La Transmission des savoir-faire : un objet pour l'ethnologie des techniques? Techniques et Culture 3: 46-83.

Childs, S. T. 1991. Style, Technology, and Iron Smelting Furnaces in Bantu-Speaking Africa. Journal of Anthropological Archaeology 10: 332-359.

Childs, S. T. and Killick, D. 1993. Indigenous African Metallurgy: Nature and Culture. Annual Review of Anthropology 22: 317-337.

Chirikure, S. Burret, R. and Heimann, R. B. 2009. Beyond furnaces and slags: a review study of bellows and their role in indigenous African metallurgical process. Azania 44.2: $195-215$.

Cline, W. 1937. Mining and Metallurgy in Negro Africa. Menasha: George Banta Publishing 5 (General series in Anthropology).

Clist, B. 2012. Vers une réduction des préjugés et la fonte des antagonismes : un bilan de l'expansion de la métallurgie du fer en Afrique Sub-Saharienne. Journal of African Archaeology 10.1: 71-84.

David, N. and Robertson, I. G. 1996. Competition and change in two traditional African iron industries. In P. R. Schmidt (ed.), The Culture and Technology of African Iron Production. Gainesville: University Press of Florida, 128-144.

Echard, N. 1986. Histoire du peuplement et histoire des techniques : l'exemple de la métallurgie hausa du fer au Niger. Journal des Africanistes 56.1: 21-34.

Eichhorn, B. 2012. Woody resource exploitation for iron metallurgy of the Fiko tradition: implications for the environmental history of the Dogon country, Mali. In C. Robion-Brunner and B. Martinelli (eds), Métallurgie du fer et sociétés africaines : bilans et nouveaux paradigmes dans la recherche anthropologique et archéologique. Oxford: Bar International Series 2395, 141-152.

Fabre, J.-M. 2009. La métallurgie du fer au Sahel burkinabé à la fin du 1er millénaire AD. In S. Magnavita, L. Koté, P. Breunig and O. A. Idé (eds), Crossroads, Cultural and 
technological developments in first millennium $B C / A D$ West Africa. Frankfort: AfricaMagna, 167-178.

Gallay, A. 2000. Cultures, styles, ethnies: quel choix pour l'archéologue ? In R. De Marinis R. and S. Biaggio Simona (eds), I Leponti: tra mito e realtà, 1. Cat. di mostra (maggio-dicembre 2000 ; Locarno, Castello Visconteo - Casorella). Locarno: Gruppo Archeologia Ticino, 71-78.

Gallay, A. 2001. Diffusion ou invention : un faux débat pour l'archéologue ? In J.-P. Descoeudres, E. Huysecom, V. Serneels and J.-L. Zimmermann (eds), Aux origines de la métallurgie du fer. Table ronde internationale d'archéologie: l'Afrique et le bassin méditerranéen (1 ; 4-7 juin 1999 ; Genève). Sydney: University of Sydney 14, 73-82.

Gallay, A. 2010. Les mécanismes de diffusion de la céramique traditionnelle dans la boucle du Niger (Mali): une évaluation des réseaux de distribution. In C. Manen, F. Convertini, D. Binder and I. Sénépart (eds), Premières sociétés paysannes de Méditerranée occidentale: structure des productions céramiques. Séance de la Société préhistorique française. Paris: Société préhistorique française, 265-281.

Gordon, R. B. and Killick, D. J. 1993. Adaptation of Technology to Culture and Environment: Bloomery Iron Smelting in America and Africa. Technology and Culture 34.2: $243-270$.

Gosselain, O. P. 1995. Identités techniques, le travail de la poterie au Cameroun méridional. Unpublished PhD thesis, ULB University, Bruxelles (Belgique).

Guillon, R. 2013. Relation société-milieu en domaine sahélien au sud-ouest du Niger au cours des quatre derniers millénaires: approche géoarchéologique. Unpublished PhD thesis, University of Dijon, Dijon (France).

Haour, A., Banni Guene, O., Gosselain, O., Livingstone Smith A. and N'Dah, D. 2011. Survey Along the Niger River Valley at the Benin-Niger Border, Winter 2011. Nyame Akuma 76: 23-32.

Herbert, E. W. 1993. Iron, Gender and Power. Rituals of transformation in African societies. Bloomington: Indiana University Press.

Holl, A. F. C. 2009. Early West African Metallurgies: New Data and Old Orthodoxy. Journal of World Prehistory 22: 415-438.

Huysecom, E. 2001. Technique et croyance des forgerons africains: éléments pour une approche ethnoarchéologique. In J.-P. Descoeudres, E. Huysecom, V. Serneels and J.-L. Zimmermann (eds), Aux origines de la métallurgie du fer. Table ronde internationale d'archéologie : I'Afrique et le bassin méditerranéen (1 ; 4-7 juin 1999 ; Genève). Sydney: University of Sydney 14, 73-82. 
Huysecom, E. 2002. Palaeoenvironment and human population in West Africa: an international research project in Mali. Antiquity 292: 335-336.

Huysecom, E. and Agustoni, B. 1996. Inagina, l'ultime maison du fer. Genève : 52 min.

Kante, N. 1993. Forgerons d'Afrique noire. Transmission des savoirs traditionnels en pays malinké. Paris: Editions de l'Harmattan.

Kense, F. J. 1985. The initial diffusion of iron to Africa. In R. Haaland and P. Shinnie (eds), African Iron Working: Ancient and Traditional. Oslo: Norwegian University Press, 11-27.

Kiethéga, J.-B. 2009. La métallurgie lourde du fer au Burkina Faso. Une technologie à l'époque précoloniale. Paris: Éditions Karthala.

Killick, D. J. 1991. The relevance of recent African iron-smelting practice to reconstructions of prehistoric smelting technology. MASCA research papers in science and archaeology 8.1: 47-54.

Killick, D. J. 2004. Review essay: What do we know about African iron working? Journal of African Archaeology 2.1: 97-112.

Killick, D. J. 2015. Invention and Innovation in African Iron-smelting Technologies. Cambridge Archaeological Journal 25.1: 307-319.

Killick, D. J. and Miller, D. M. 2014. Smelting of magnetite and magnetite-ilmenite ores in the northern Lowveld, South Africa, ca. 1000 CE-ca.1880 CE. Journal of Archaeological Science 43: 230-255.

Langlois, O. 2005-06. De l'organisation bipartite du travail du fer dans les monts Mandara septentrionaux. Techniques et cultures 46-47: 175-209.

Lemonnier, P. 2010. L'étude des systèmes techniques. Techniques et Cultures 54-55.1: 49-67.

Leroi-Gourhan, A. 1971. Evolution et techniques. L'homme et la matière. Paris: Albin Michel (1 $1^{\text {st }}$ ed. 1943).

de Maret, P. 1980. Ceux qui jouent avec le feu: la place du forgeron en Afrique Centrale Africa. Journal of the International African Institute 50.3: 263-279.

de Maret, P. 1985. The smith's myth and the origin of leadership in Central Africa. In R. Haaland and P. Shinnie (eds), African Iron Working: Ancient and Traditional. Oslo: Norwegian University Press, 73-87.

Martinelli, B. 1993. Fonderies ouest-africaines. Classement comparatif et tendances. Techniques et cultures 21: 195-221. 
Martinelli, B. 1996. Sous le regard de l'apprenti - Paliers de savoir et d'insertion chez les forgerons Moose du Yatenga (Burkina Faso). Techniques et Cultures 58: 9-47.

Martinelli, B. 2004. On the Threshold of Intensive Metallurgy: The Choice of Slow Combustion in the Niger River Bend (Burkina Faso and Mali). In H. Bocoum (ed.), 2004. The Origins of Iron Metallurgy in Africa. New Light on its Antiquity: West and Central Africa. Paris: UNESCO, 165-188.

Mauny, R. 1952. Essai sur l'histoire de métaux en Afrique occidentale. Bulletin de I'Institut Français de l'Afrique Noire 14.2: 545-595.

Mauss, M. 1947. Manuel d'ethnographie. Paris: Payot.

McNaughton, P. R. 1993. The Mande Blacksmith: Knowledge, Power, and Art in West Africa. Bloomington and Indianapolis: Indiana University Press.

Miller, D. E., and Van der Merwe, N. J. 1994. Early Metal Working in Sub-Saharan Africa: a Review of Recent Research. Journal of African History 35.1: 1-36.

Perret, S. and Serneels, V. 2006. Technological characterization and quantification of a large scale iron smelting site in Fiko, Mali. In J.-F. Moreau, R. Auger, J. Chabot and A. Herzog (eds), Proceedings / Actes ISA2006, 36th International Symposium on Archaeometry ISA 2006, Quebec Canada, 2-6.05.2006. Québec: Cahiers d'archéologie du CELAT 25.7, 453-463.

Pleiner, R. 2000. Iron of Archaeology. The European Bloomery Smelters. Praha: Archeologicky ustav AV CR.

Pole, L.-M. 1985. Furnace Design and the Smelting Operation: A Survey of Written Reports of Irin in West Africa. In R. Haaland and P. Shinnie (eds), African Iron Working: Ancient and Traditional. Oslo: Norwegian University Press, 142-163.

Robion-Brunner, C. 2010. Peuplements des forgerons et traditions sidérurgiques : Vers une histoire de la production du fer sur le plateau de Bandiagara (pays dogon, Mali) durant les empires précoloniaux. Francfort: Africa Magna Verlag.

Robion-Brunner, C. 2012. The Role of Ethnohistoric Data in Reconstructing Ancient Siderurgy in Dogon Country (Mali).P@lethnology 4: 209-234.

Robion-Brunner, C. in prep. Ironworking traditions. In Haour, A. (ed.), Birnin Lafiya: 2000 years in a Dendi village. Francfort: Africa Magna Verlag.

Robion-Brunner, C., Aboki, T. de Barros, P., Coustures, M.-P., Ilaboti, D., Dugast, S., Eichhorn, B., Le Drezen, Y., Mahou-Hekinian, V., Robert, V., Soulignac, R. and Tidjougouna, L. 2014. The Project 'SIDERENT'. Poster of the $14^{\text {th }}$ Congress of the Pan 
African Archaeological Association for Prehistory and Related Studies, University of Johannesburg, Johannesburg.

Robion-Brunner, C., Haour, A., Coustures, M.-P., Champion, L. and Béziat, D. 2015. Iron Production in Northern Benin: Excavations at Kompa Moussékoubou. Journal of African Archaeology 13.1: 39-57.

Robion-Brunner, C., Serneels, V. and Perret, S. 2013. Variability in iron smelting practices: confrontation of technical, cultural and economic criteria to explain the metallurgical diversity in the Dogon area (Mali). In J. Humphris and T. Rehren (eds), The World of Iron. London: Archetype Publications, 257-265.

Schmidt, P. R. 1996. Cultural representations of African iron production. In P. Schmidt (ed.), The culture and technology of African iron production. Gainesville: Press of Florida, 1-28

Serneels, V., Donadini, F., Kiénon-Kaboré, H.T., Koté, L., Kouassi, S.K., Ramseyer, D. and Simporé L. 2014. Origine et développement de la métallurgie du fer au Burkina Faso et en Côte d'Ivoire. Avancement des recherches en 2013 et quantification des vestiges de Korsimoro (Burkina faso). Jahresbericht 2013 der Schweizerisch-Liechtensteinische Stiftung für Archäologische Forschungen im Ausland (SLSA): 65-112.

Serneels, V., Jobin, P., Kiénon-Kaboré, H.T., Koté, L., Kouassi, S.K., Ramseyer, D. Thiombiano-Ilbi-oudo, E. and Simporé L. 2015. Origine et développement de la métallurgie du fer au Burkina Faso et en Côte d'Ivoire. Seconde champagne dans la region de Kaniasso (Folon, Côte d'Ivoire) et autres recherches. Jahresbericht 2014 der Schweizerisch-Liechtensteinische Stiftung für Archäologische Forschungen im Ausland (SLSA): 23-60.

Serneels, V., Kiénon-Kaboré, H.T., Koté, L., Kouassi, S.K., Mauvilly, M., Ramseyer, D. and Simporé, L. 2013. Origine et développement de la métallurgie du fer au Burkina Faso et en Côte d'Ivoire. Premiers résultats sur le site sidérurgique de Siola (Kaniasso, Danguélé, Côte d'Ivoire). Jahresbericht 2012 der Schweizerisch-Liechtensteinische Stiftung für Archäologische Forschungen im Ausland (SLSA): 113-143.

Serneels, V., Kiénon-Kaboré, H.T., Koté, L., Kouassi, S.K., Ramseyer, D. and Simporé, L. 2012. Origine et développement de la métallurgie du fer au Burkina Faso et en Côte d'Ivoire. Premiers résultats sur le site sidérurgique de Korsimoro (Sanmatenga, Burkina Faso). Jahresbericht 2011 der Schweizerisch-Liechtensteinische Stiftung für Archäologische Forschungen im Ausland (SLSA): 23-54.

Shinnie, P. L. 1985. Iron working at Meroe. In R. Haaland and P. Shinnie (eds), African Iron Working: Ancient and Traditional. Oslo: Norwegian University Press, 28-35.

Sutton, J. E. G. 1985. Temporal and spatial variability in African iron furnaces. In R. Haaland and P. Shinnie (eds.), African Iron Working: Ancient and Traditionnal. Oslo: Norwegian University Press, 164-191. 
Trigger, B. G. 1969. The myth of Meroe and the African Iron Age. International Journal of African Historical Studies 2: 23-50.

Tylecote, R. F. 1987. The early history of metallurgy in Europe. London: Longman.

Van der Merwe, N. J. and Avery, D. H. 1987. Science and Magic in African Technology: Traditional Iron Smelting in Malawi. Africa 57.2: 143-172.

Viennot, M. 1978. Notice explicative $n^{\circ} 66$ (9) de la carte pédologique de reconnaissance de la République Populaire du Bénin, Feuille de Kandi-Karimama. Paris: Orstom. 